\title{
Bacteriocins from lactic acid bacteria inhibit food borne pathogens.
}

\author{
Princewill-Ogbonna, I. L. and Ojimelukwe, P. C. \\ Department of Food Science and Technology, Michael Okpara University of Agriculture, Umudike com
}

\begin{abstract}
Lactic acid bacteria were isolated from naturally fermenting food products (ogi, nunu and soybean). They were screened for their ability to produce bacteriocins and inhibit two pathogenic organisms. Twenty four lactic acid bacteria were isolated. Eight were catalase negative. Their probable identities were: Lactobacillus acidophilus, Lactobacillus plantarum, Lactobacillus fermentum, Lactobacillus acidophilus, Leuconostoc lactis, Pediococcus pensaceus, Leuconostoc mesenteriodes and organism $F$ (identity not confirmed). Extracellular extracts of the eight isolates inhibited pathogenic strains of Escherichia coli (ATCC 117755) and Staphylococcus aureus (ATCC 12600). Inhibition zones ranged from 9.67 to $19.33 \mathrm{~mm}$ against E. coli and 7.33 to $15.00 \mathrm{~mm}$ against $S$. aureus. L. acidophilus and the control (subtilisin) had the highest inhibition zones (15 $\mathrm{mm})$ against $S$. aureus, while L. fermentum had the highest inhibition zone $(19.33 \mathrm{~mm})$ against E. coli. After treatment with catalase, the inhibition zones for $L$ mesenteroides, $P$ pentosaceus and L. lactis against S.aureus became virtually non-existent $(0.3-1.0 \mathrm{~mm})$ indicating that the inhibitory substance was of a non-protein nature. The same trend was observed for the inhibitory effects of these organisms on E.coli (inhibitory zones of 0.00 to 0.67 after treatment with catalase). L acidophilus, L. plantarum and L. fermentum produced bacteriocin. Their inhibition zones were maintained after treatment with catalase but became non-existent after treatment with proteinase $K$.
\end{abstract}

Keywords: food borne pathogens, inflammatory diseases, bacteriocins, lactic acid bacteria

\section{Introduction}

Lactic acid bacteria are industrially important organisms recognized for their fermentative ability, health and nutritional benefits. Species used for food fermentations belong to the genera Lactococcus, Streptococcus, Pediococcus, Leuconostoc, Lactobacillus, and the newly recognized Carnobacterium. Lactic acid bacteria (LAB) occur naturally in several raw materials like milk, meat and flour. They are used to produce many fermented foods [1]. One important attribute of lactic acid bacteria is their ability to produce antimicrobial compounds such as organic acids, diacetyl, hydrogen peroxide, ethanol, reuterin and bacteriocins or bactericidal proteins $[2,3]$. In recent years, interest in bacteriocins has grown substantially due to their potential usefulness as natural food preservatives in addition to promoting good health [3]. Selected strains of lactic acid bacteria, used as starter culture, may inhibit spoilage microorganisms and pathogens by production of metabolites with anti microbial properties [4]. Different lactobacilli, bifidobacteria, or probiotic mixtures have been shown to alleviate digestive diseases in experimental animals $[5,6)$ and in inflammatory bowel diseases in humans $[7,8$, 9] Pathogenic Escherichia coli induce acute inflammatory responses while Staphylococcus aureus elicit mild inflammatory responses that may be more persistent [10]. Bacteriocins produced by lactic acid bacteria are defined as extracellular primary or modified products of bacterial ribosomal synthesis, which can have relatively narrow spectrum of bactericidal activity [11]. Health benefits currently being investigated in favor of probiotic microorganisms include their role in alleviating chronic intestinal inflammatory diseases; prevention and treatment of pathogen induced diarrhea; urogenital infections and atopic diseases[12,13,14] Bacteriocin producing strains can be used as part of an adjunct to starter cultures for fermented foods in order to improve safety and manage health more effectively [15]. Several bacteriocins with industrial potential have been purified and characterized. Bacteriocins of lactic acid bacteria, according to the classification are divided into four classes [16].. Nowadays, the consumer pays better attention to the relation between food and health [17]. The use of functional starter cultures in food fermentation tailor made for increased bacteriocin production is being explored for improved healthcare and disease management [18]. The target of bacteriocins is usually the cytoplasmic membrane. There is need to improve bacteriocin production in Lactic acid bacteria for health benefits. The present research is a preliminary attempt to ascertain bacteriocin production by different strains of lactic acid bacteria and their efficacy against the antagonistic affects of pathogenic bacteria. In course of the research, lactic acid bacteria will be isolated from selected fermented foods (ogi, nunu and soybean) and tested for their bacteriocin producing potentials. Those with good potentials could serve as adjuncts for accelerated food fermentations to reduce and manage inflammatory diseases caused by food borne pathogens. 


\section{Materials and methods \\ 2.1 Preparation of samples used for the isolation of lactic acid bacteria}

Ogi: The ogi used for this research was prepared traditionally according to the method of [19]. The grains of Zea mays were cleaned and steeped in water for 2 days in a pot. The water was decanted and grains wet-milled before sieving with muslin cloth. The pomace was discarded and the starch suspension was allowed to sediment and fermentation was carried out for 3 days during which the fermenting natural flora was isolated. Soybean: Thirty (30) grams of soybean seeds were soaked in $150 \mathrm{ml}$ of water. The water was changed at intervals to reduce microbial growth on the seeds. After steeping for eight hours, 10 grams was pounded and added into $90 \mathrm{ml}$ of $0.1 \%$ sterile peptone water, incubated for 24 hours at $30^{\circ} \mathrm{C}$ and used for isolation of microorganisms.

Nunu: Ten (10) grams of fresh nunu (naturally fermenting cow milk) was added into $90 \mathrm{ml}$ of $0.1 \%$ sterile peptone water, incubated for 24 hours at $30^{\circ} \mathrm{C}$ and the fermenting microorganisms were isolated.

\subsection{Isolation and screening for bacteriocin-producing lactic acid bacteria from Ogi, soybean and nunu:}

Isolation and screening of bacteria-producing lactic acid bacteria was done as described by Todorov et al. [19] with little modification. One milliliter of each of the prepared samples from ogi, soybean and nunu was innnoculated into $9 \mathrm{ml}$ sterile De Man Ragosa and Sharpe (MRS) broth (Fluka, UK) for enrichment of the resident $\mathrm{LAB}$. The tubes were incubated at $30^{\circ} \mathrm{C}$ for 48 hours. The aliquots $(1 \mathrm{ml})$ of the culture from each of the tubes were diluted serially to $10^{10}$ times and $1 \mathrm{ml}$ was spread evenly on MRS agar plates. The plates were incubated at $30^{\circ} \mathrm{C}$ for 16 hours till colonies appeared.

The indicator or target organisms (Escherichia coli, ATCC 117755 and Staphylococcus aureus, ATCC 12600) were grown overnight in nutrient broth. A volume of $1 \mathrm{ml}$ of the indicator organisms, with a total of approximately $5 \times 10^{5} \mathrm{cfu} / \mathrm{ml}$ were seeded into $15 \mathrm{ml}$ of semi-solid MRS agar. After agitation they were poured over the plates containing MRS agar on which the strains under test had grown. The plates were incubated at $30^{\circ} \mathrm{C}$ for 24 hours and checked for inhibition zone. Inhibition was considered positive when the inhibition halo of the indicator strains above the $\mathrm{LAB}$ colonies were more than $2 \mathrm{~mm}$ and such bacteria were considered as potential bacteriocin producers. Such colonies were carefully collected and transferred into MRS broth (different tubes for each colony). The colonies were purified by plating on MRS agar. This procedure was repeated in order to further purify the isolates. The purified colonies were maintained on MRS agar slants for immediate use and in $20 \%$ glycerol for storage at $20^{\circ} \mathrm{C}$ [20].

\subsection{Identification of the isolates:}

Isolates obtained from the screening test were identified by conventional microbiological and biochemical procedures, which included microbial examination of cell morphology and biochemical tests (gram reaction, catalase test, mobility test, arginine test, growth at $4 \%, 6.5 \% \mathrm{NaCl}$ for 72 hours at $30^{\circ} \mathrm{C}$ and sugar fermentation tests). The sugars used were glucose, L-arabinose, dextrose, D-fructose, D-xylose, galactose, raffinose, sorbitol, and sucrose.

2.4 Determination of the inhibition zone of the isolates at $30^{\circ} \mathrm{C}$ for 72 hours against Staphylococcus aureus ATCC 12600, and E. coli ATCC 117755 using agar well diffusion test

Eight isolates were tested for antimicrobial activity. One milliliter of the indicator strains (with approximately $5 \times 10^{5} \mathrm{cfu} / \mathrm{ml}$ ) cultured in nutrient broth at $30^{\circ} \mathrm{C}$ for 18 hours was seeded into $15 \mathrm{ml}$ of semi-solid nutrient agar, and Mackonkey agar (for ATCC 12600 and ATCC 117755 respectively). After solidification of the agar, a well of $5 \mathrm{~mm}$ diameter was aseptically cut into it and $1 \mathrm{ml}$ of the fluid from the cultured strains under test (for antimicrobial activity) obtained as indicated above was added to each well. The plates were kept at $47^{\circ} \mathrm{C}$ for 4 hours to ensure diffusion of the fluid into the agar and examined for inhibition after incubation at $30^{\circ} \mathrm{C}$ for 24 , 48 and 72 hours [21].

\subsection{Preparation of the cell-free supernatant:}

The strains that possessed antimicrobial activity but had negative result for hydrogen peroxide were used to prepare the cell-free supernatant. The strains were incubated in MRS broth (Fluka) at $30^{\circ} \mathrm{C}$ for 24 hours. Subsequently, the $\mathrm{pH}$ of the culture was adjusted to 6.5 with sterile $1 \mathrm{M} \mathrm{NaOH}$. The culture was then centrifuged at $3000 \mathrm{~g}$ for 15 minutes and sterilized by filtration through a $0.22 \mu \mathrm{m}$ pore size membrane filter (Whatman). 2.6 Sensitivity of the cell-free supernatant (bacteriocin-like substance) to enzyme (catalase and protenase K): One milliliter of sterile cell-free supernatant obtained as described above were incubated for 2 hours at $37^{\circ} \mathrm{C}$ in the presence of $1 \mathrm{mg} / \mathrm{ml}$ catalase (Fluka) and proteinase K (Sigma) and catalase and later inactivated in a water bath for 10 minutes. Control experiments used were cell-free supernatant without enzyme treatment and 1 $\mathrm{mg} / \mathrm{ml}$ of subtilisin. Antimicrobial activity of each of the isolates was determined by agar well diffusion test with E. coli ATCC 117755 and Staphylococcus aureus ATCC 12600 as indicator organisms. 


\subsection{Identification of the isolates}

\section{Results}

Ten (10), six (6) and eight (8) strains of lactic acid bacteria were isolated from ogi, nunu and soybean respectively. After screening to eliminate catalase positive organisms, only eight isolates remained. Table 1 shows the characteristics of these eight isolates. The colony morphology and biochemical characterization of the isolates were studied. Majority of the strains were rods while some were cocci. Lactobacillus fermentum, Lactobacillus acidophilus (two of the isolates), Pediococcus pentasecens were able to liberate ammonia from arginine, while Lactobacillus plantarium, Leuconostoc mesenteriodes and Leuconostoc lactis were not able to liberate ammonia from arginine.

All the isolates were able to grow at $15^{\circ} \mathrm{C}, 4 \%$ and $6.5 \% \mathrm{NaCl}$ and were able to utilize glucose to produce acid but only three (Lactobacillus fermentum, Lactobacillus acidophilus and Lactobacillus plantarum) were able to produce gas in addition to the acid. Lactobacillus fermentum was able to utilize all the fourteen sugars. Dextrose, D-fructose, galactose, mannose, melebiose were utilized by all the isolates. Organism F displayed a peculiar characteristic by producing gas bubbles in seven out of the fourteen sugars used for the test .The probable identity of this isolate could not be determined using normal biochemical tests.

3.2 Effect of period of incubation on the inhibition zone of the isolates against Staphylococcus aureus Table 2 shows the inhibition zones of test organisms against Staphylococcus aureus at varying incubation periods. There were no significant differences $(\mathrm{p}>0.05)$ in the inhibition zones of Lactobacillus fermentum, Lactobacillus acidophilus, Leuconostoc mesenteriodes and Leuconostoc lactis between 24 and 72 hours of incubation. For Lactobacillus plantarum, there was no observable inhibition zone after 72 hours. The degree of inhibition of Lactobacillus plantarum against $S$. aureus was not significantly different $(\mathrm{p}>0.05)$ within the first 48 hours.

3.3 Effect of catalase and proteinase $\mathrm{K}$ enzymes on the antimicrobial properties of some lactic acid bacteria against Escherichia coli (ATCC 117755) and Staphylococcus aureus (ATCC 12600)

The antimicrobial activities exhibited by Lactobacillus fermentum, Lactobacillus acidophilus and Lactobacillus plantarum against Staphylococcus aureus (ATCC 12600) were found to be insensitive to the action of catalase enzyme. There was no significant reduction in the inhibition zone exhibited by these isolates (Table 5). On the other hand, the antimicrobial activity exhibited by these organisms against Staphylococcus aureus was found to be sensitive to the action of protease enzyme. Thus, incubation of the extracellular extract obtained from these isolates together with proteinase $\mathrm{K}$ elicited a significant loss $(\mathrm{p}<0.05)$ of the antimicrobial activity, as determined by the agar well diffusion test.

There was significant reduction in the antimicrobial activity of Leuconostoc lactis, Pediococcus pentasaceus, Leuconostoc mesenteroides and organism F "not determined" (Table 5) after treatment with catalase enzyme. No significant reduction in the inhibition zone was observed after treating the extracellular extract of these isolates with proteinase K using Staphylococcus aureus as the target organism.

Subtilisin (a known bacteriocin) was used as the control and no significant reduction in the antimicrobial activity was observed after treatment with catalase. Meanwhile, significant inactivation in the antimicrobial activity of subtilisin was recorded after treatment with proteinase $\mathrm{K}$.

3.4 Effect of different enzymes (catalase and proteinase $\mathrm{K}$ ) on the inhibitory property of some lactic acid bacteria against Escherichia coli (ATCC 117755)

Treatment with catalase did not alter the antimicrobial activities of the extracellular extract of Lactobacillus acidophilus, Lactobacillus plantarum and Lactobacillus acidophilus against E. coli. Complete inactivation or significant reduction in the antimicrobial activity was observed after treatment of the extracellular extract of same organisms with proteinase $\mathrm{K}$ (Table 6).

Complete inactivation or significant reduction in antimicrobial activity was observed after treatment of the cell-free supernatant of Leuconostoc mensenteriodes, organism F, Pediococcus pentosaceus and Leuconostoc lactis with catalase. The antimicrobial activity of the extracellular extract of same organisms was not affected significantly $(\mathrm{P}>0.05)$ after treatment with proteinase $\mathrm{K}$. No significant reduction in the antimicrobial activity of subtilisin (control) was observed after treatment with catalase while significant reduction was observed in the antimicrobial activity of subtilisin (control) after treatment with proteinase K.

\section{Discussion}

The identification test carried out on the food isolates indicated the dominance of lactic acid bacteria in the ogi, nunu and soybean. Similar result was obtained by Odunfa and Adeyele [20]. Incubation period did not affect the antimicrobial activity of the isolates for at least 72 hours except for Lactobacillus acidophilus. The isolates had progressive growth until the $66^{\text {th }}$ hour except for Lactobacillus fermentum. The sharp decrease in 
$\mathrm{pH}$ of the isolates during 6-18 hours of incubation in MRS broth was due to the production of acids especially lactic acid. Production of acids has been reported to be higher during the stationary phase.

The antimicrobial activity of the lactic acid bacteria may be due to a number of factors. Among these are decreased $\mathrm{pH}$ levels, competition for substrate, and the production of substances with bacteriocidal or bacteriostatic action including bacteriocin [22]. In fact, the drop in $\mathrm{pH}$ arising from the production of lactic is enough to inhibit certain strains. This is because the non-dissociated form of lactic acid triggers a lowering of the internal $\mathrm{pH}$ of the cell that causes a collapse in the electrochemical proton gradient in sensitive bacteria, hence a bacteriostatic or bacteriocidal effect [23]. Probiotic bacteria have been observed by other researchers to have a beneficial effect on intestinal inflammation. Menard et al.(26] observed inhibition of polysaccharide induced secretion of Tumor Necrosis Factor (TNF- $\alpha$ ) by Streptococcus thermophilus and Bifidobacterium breve. All the eight strains that showed negative result during catalase test inhibited the reference strains $(E$. coli ATCC 117755 and S. aureus ATCC 12600). The use of sterile base (1M NaOH) and catalase (Sigma) was to exclude any antimicrobial action arising from organic acids and from hydrogen peroxide respectively [21]. The antimicrobial activities of all the strains were not altered after excluding the possibility of organic acid as the cause of the inhibition.

When the neutralized extra-cellular extract from all the isolates was treated with catalase (Sigma), only four (neutralized extracellular extract from Lactobacillus fermentum, L. acidophillus and L. plantarum, $L$. acidophillus) out of the eight retained their microbial activity. This shows that hydrogen peroxide may have been the cause of antimicrobial activity exhibited by Leuconostoc mesenteroides, Pediococcus pentasaceus, Leuconostoc lactis and organism F (identity not confirmed).

The differences in inhibition zones and patterns observed for E.coli and S. aureus support observations that pathogenic organisms elicit responses in their host through different mechanisms. In humans, E. coli activates the TLR4 receptor while peptodiglycans found in gram positive bacteria such as $S$. aureus elicit inflammatory responses through activation of TLR2 receptor [25]. The ability of bacteria to establish infection is mediated in part by the ability of the host to respond to the invading organism [26]. The differences in responses of $E$. coli and $S$. aureus to different lactic acid bacteria maybe attributed to the nature and observable symptoms associated with their pathogenic effects [27,28]

Complete inactivation or significant reduction in antimicrobial activity of the neutralized extracellular extract of L. acidophillus, L. plantarum, L. fermentum and L. acidophillus was observed after treatment with proteinase K (Fluka, UK), confirming their proteolytic nature [28]. The cell free supernatant of the isolates lost their antimicrobial activity after treatment with proteinase $\mathrm{K}$. This shows that out of the three Nigerian indigenous foods, nunu and ogi had better potentials for producing lactic acid bacteria with bio-preservative effects and health benefits (bacteriocin). The differences in the inhibition zones before and after treatment with catalase and proteinase $\mathrm{K}$ suggest that different responses were elicited by different bacteria pathogens.

\section{Conclusion}

Preventive health care can be effectively enhanced by the intake of foods that discourage pathogens that cause infections. Lactic fermentation with organisms like Lactobacillus acidophilus, Lactobacillus plantarum, Lactobacillus fermentum promote wholesomeness of foods and health of individuals by discouraging the growth of pathogenic bacteria like $E$. coli and $S$ aureus. Some of the inhibitory metabolites from the lactic acid bacteria are susceptible to proteolysis suggesting that they are proteins and might be bacteriocins.

\section{Acknowledgement}

The authors wish to thank Dr. Eze Uche from the Department of Microbiology, University of Nigeria, Nsukka for providing us with the target organisms used for this work.

\section{References}

[1]. E. Rodriguez, B. Gonzalis, P. Gaya, M. Nunez, M, Media. Diversity of bacteriocin production/lactic acid bacteria isolated from raw milk. International. Dairy Journal. 10, 2000, 7-15

[2]. V.O. Oyetayo, F.C.Adetuyi, F.A. Akinyosoye. Safety and Protective effect of Lactobacillus acidophilus and Lactobacillus casei used in as probiotic agent in vivo. African Journal of . Biotechnology, 2, 2003, 448-452

[3]. A. Savadogo, C. Ovattara, C. Bassole, H.N. Imael, S.A.Traose. Bacteriocins and lactic acid bacteria - a minireview. African Journal of Biotechnology, 5(9), 2006, 678-683

[4]. H. Albano, S.D.Todorov, C.A.Van Reeren, T.Hogg, L.M.T.Dick. Teixerina P. Characterization of two bacteriocin produced by Pediococcus acidilactic isolated from "Alherira" a fermented sausage traditionally produced in Portugal. International Journal of Food Microbiology, 11, 2007, 239-247.

[5]. K.Madsen, A. Cornish, P. Soper. Probiotic bacteria enhance murine and human intestinal epithelial barrier function. Gastroenterology. 121, 2001, 580-91.

[6]. K.I.Madsen, J.S.Doyle, L.D. Jewell. Lactobacillus species prevents colitis in interleukin 10 gene-deficient mice. Gastroenterology, 116:1999, 1107-14. 
[7]. P. Gionchetti, F.Rizzello, A.Venturi. Oral bacteriotherapy as maintenance treatment in patients with chronic pouchitis: a doubleblind, placebo-controlled trial. Gastroenterology, 119, 2000, 305-309

[8]. P.Gupta, H.Andrew, B.S.Kirschner. Is lactobacillus GG helpful in children with Crohn's disease? Results of a preliminary openlabel study. Journal of Pediatrics and Gastroenterology Nutrition, 31,2000,453-457.

[9]. N.Borruel, M. Carol, F. Casellas. Increased mucosal tumour necrosis factor alpha production in Crohn's disease can be down regulated ex vivo by probiotic bacteria. GUT; 51, 2002, 659-4.

[10]. T.H. Mogensen, Pathogen recognition and inflammatory signaling in innate immune defenses. Clinical Microbiology Review, 22, 2009, 240-273

[11]. E. Caplice, G.F. Fitzgerald. Food fermentation: role of microorganisms in food production and preservation. International Journal of Food Microbiology, 50, 1999, 131-149

[12]. C.Hessle, B. Andersson, A.E. Wold. Gram-positive bacteria are potent inducers of monocytic interleukin-12 (IL-12) while gramnegative bacteria preferentially stimulate IL-10 production. Infection and. Immunology, 68, 2000, 3581-3586.

[13]. F.Yan, D.B.Polk. Probiotics as functional food in the treatment of diarrhea. Current Opinion in Clinical Nutrition and Metabolic Care, 9 (6) 717-721

[14]. Reid G Probiotic Lactobacilli for urinogenital health in women. Journal of Clinical Gastroenterology. 40, 2008, Supplement 3 part 2. S234-235

[15]. J.A.Vanderhoof . 2008. Probiotics in allergy management. Journal of Pediatric Gastroenterology and Nutrition 47.2008, Supplement 2 S38-40

[16]. Schmidt, Jorgen. "Health and Nutritional Properties of Probiotics in Food including Powder Milk with Live Lactic Acid Bacteria". Report of a Joint FAO/WHO Expert Consultation on Evaluation of Health and Nutritional Properties of Probiotics in Food Including Powder Milk with Live Lactic Acid Bacteria. FAO / WHO. Retrieved 17 December 2012

[17]. K.Alfaleh, J. Anabrees, D. Bassler, \& T. Al-Kharfi, T. Probiotics for prevention of necrotizing enterocolitis in preterm infants. Cochrane Database of Systematic Reviews (Online), 2011 (3), CD005496. doi:10.1002/14651858.CD005496.pub3 \}

[18]. J. Bravo, Javier. "Ingestion of Lactobacillus strain regulates emotional behavior and central GABA receptor expression in a mouse via the vagus nerve" Proceedings of the National Academy of Sciences, 108 (38), 2011, 16050-5. doi:10.1073/pnas.1102999108. PMC 3179073

[19]. S.D. Torodov, H. Nyati, M. Meinicken, L.M.T.Dicks. Partial characterization of bacteriocin AMA-K produced by lactobacillus plantarum AMA-K isolated from naturally fermented milk from Zimbabwe. Journal of Food Control. 18, 2007, 656-656-664

[20]. S.A. Odunfa, S.T. Adeleye Microbial changes during the traditional production of ogi, baba, a West African fermented sorghum gruel. Journal of Cereal Sciences, 3, 1985, 173-180

[21]. F.M.A.Ahmad, K.P.T.Irene. On the safety of lactic acid bacteria from food. International. Journal of Food Microbiology, 27, 2006, 263-264.

[22]. L.Gonzalez, H.Sandoval, N.Sacristan, J.M.Castro, J.M. Fresno, M.E. Tornadijo. Identification of lactic acid bacteria isolated from Genestoso cheese throughout ripening and study of their antimicrobial activity. Journal of Food Control, 18, 2007, 716-722.

[23]. Parente E, Ricciardi A. Production, recovery and purification of bacteriocin from lactic acid bacteria. Applied Microbiology and Biotechnology, 52, 1999, 628-638..

[24]. T. O'Keeffee, and C. Hill. Bacteriocin potential in food preservation.1999. Available from http://www.foodscience.cornell.edu/fs406/bacteriocin.doc

[25]. N.W.Schreder, S.Morath, C. Alexander, L.Hamann, T.Hartung, U. Zahringer, U.B.J. Gobel, J. R. Weber, R.R.Schumann. Lipoteichoic acid (LTA) of Streptococcus pneumoniae and Staphylococcus aureus activates immune cells via Toll-like receptor (TLR)-2, lipopolysaccharide-binding protein (LBP), and CD14, whereas TLR-4 and MD-2 are not involved. Journal of. Biological. Chemistry. 278, 2003, 15587-15594

[26]. S.Menard, C. Candalh, J.C.Bamboo, K.Terpend, N. Cerf-Bensussan, M. Hevman. Lactic acid bacteria secrete metabolites retaining anti inflammatory properties after intestinal transport. GUT, 53(6), 2004, 821-828.

[27]. S.Redpath, P. Ghazal, N.R.Gascoigne . Hijacking and exploitation of IL-10 by intracellular pathogens. Trends in Microbiology. 9, 2001, 86-92.

[28]. J.M.A.Fierer, D. Swancutt, G.Heumann, D. Golenbock.. The role of lipopolysaccharide binding protein in resistance to Salmonella infections in mice. Journal of Immunology. 168, 2002, 6396-6403

[29]. S.Morath, A. Stadelmaier,A. Geyer, R.R. Schmidt, T. Hartung . Synthetic lipoteichoic acid from Staphylococcus aureus is a potent stimulus of cytokine release. Journal of. Experimental. Medicine.:195, 2002, 1635-1640

C.A.Van Reenen, L.M.T.Dicks, M.L.Chikindas. Isolation, purification and partial characterization of plantaricin 423, a bacteriocin produced by Lactobacillus plantarum. Journal of Applied Microbiology, 184:1998 1131-1137 


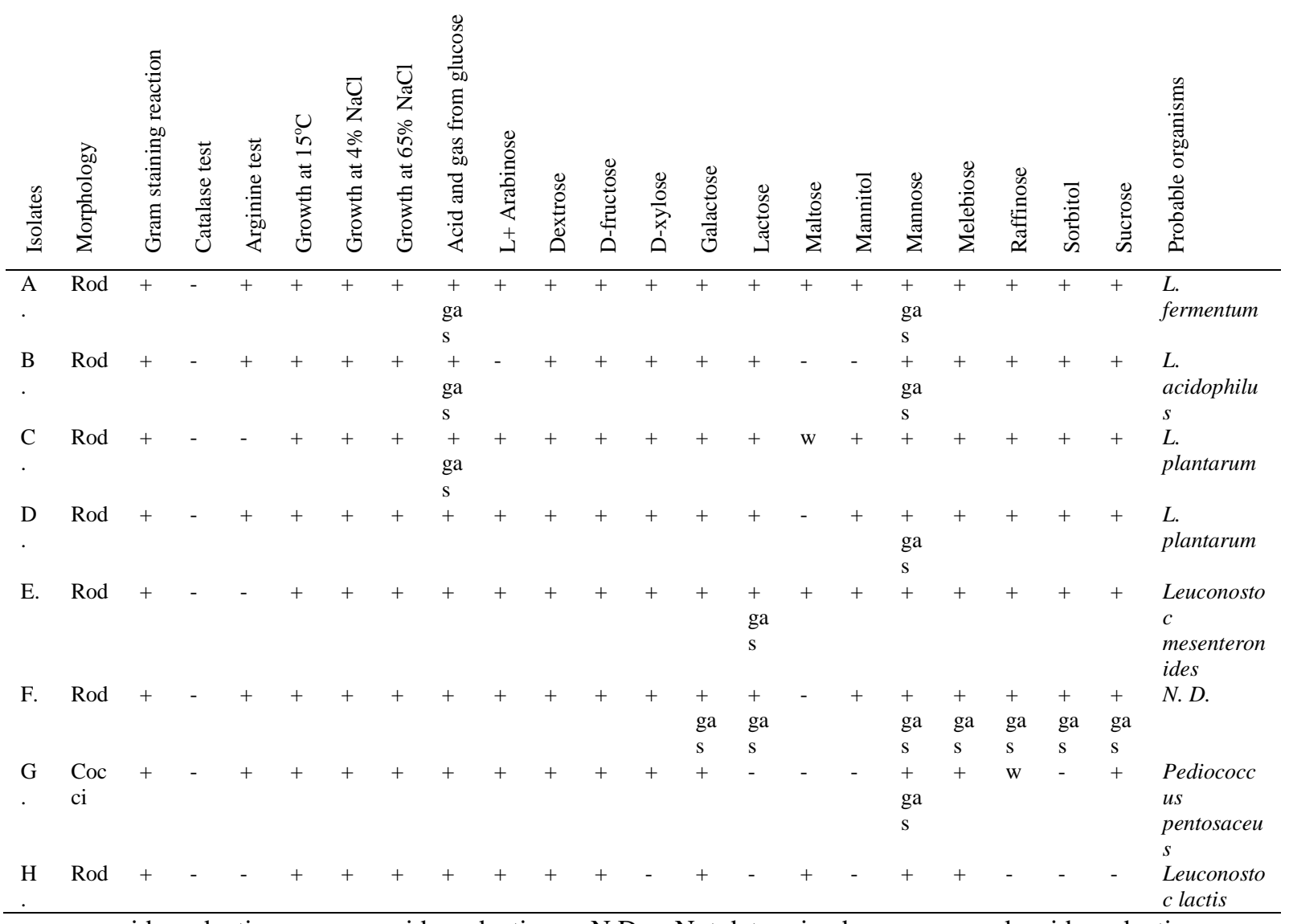

$+=\quad$ acid production; $-=$ no acid production; $\quad$ N.D. $=$ Not determined; $\quad \mathrm{w}=$ weak acid production.

Table 2 Inhibition zone of some lactic acid bacterial against Staphylococcus aureus

\begin{tabular}{|c|c|c|c|c|}
\hline Organisms & $\begin{array}{l}24(\mathrm{~h}) \\
\text { inhibition zone (mm) }\end{array}$ & $\begin{array}{l}48(\mathrm{~h}) \\
\text { inhibition zone (mm) }\end{array}$ & $\begin{array}{l}72(h) \\
\text { inhibition zone }(\mathrm{mm})\end{array}$ & SEM \\
\hline Lactobacillus fermentum & $13.33^{\mathrm{a}}$ & $16.00^{\mathrm{a}}$ & $13.67^{\mathrm{a}}$ & 0.69 \\
\hline Lactobacillus acidophilus & $14.67^{\mathrm{a}}$ & $16.33^{\mathrm{a}}$ & $13.67^{\mathrm{a}}$ & 0.89 \\
\hline Lactobacillus plantarum & $15.67^{\mathrm{a}}$ & $18.33^{\mathrm{a}}$ & ND & 3.01 \\
\hline Lactobacillus acidophilus & $18.00^{\mathrm{a}}$ & $20.67^{\mathrm{a}}$ & $15.67^{\mathrm{a}}$ & 1.01 \\
\hline Leuconostoc mesenteroides & $12.67^{\mathrm{a}}$ & $16.33^{\mathrm{a}}$ & $14.67^{\mathrm{a}}$ & 1.04 \\
\hline $\begin{array}{ll}\begin{array}{l}\text { OrganismF(Not } \\
\text { characterized) }\end{array} & \text { fully }\end{array}$ & $5.67^{\mathrm{b}}$ & $8.00^{\mathrm{ab}}$ & $10.00^{\mathrm{a}}$ & 0.77 \\
\hline Pediococcus pentosaceus & $12.67^{\mathrm{ab}}$ & $21.00^{\mathrm{a}}$ & $21.67^{\mathrm{a}}$ & 1.97 \\
\hline Leuconostoc lactis & $18.67^{\mathrm{a}}$ & $23.00^{\mathrm{a}}$ & $20.67^{\mathrm{a}}$ & 1.05 \\
\hline
\end{tabular}

$\mathrm{a}, \mathrm{b}=$ means with different superscripts in the same row are significantly different at $(\mathrm{P}<0.05)$

SEM $=$ standard error of means

$\mathrm{ND}=$ not determined

Table 4.Inhibition of Escherichia coli by Lactic acid Bacteria

\begin{tabular}{lllll}
\hline Organisms & Inhibition Zone $(\mathrm{mm})$ & & & \\
\hline & $24 \mathrm{~h}$ & $48 \mathrm{~h}$ & $72 \mathrm{~h}$ & SEM \\
\hline $\begin{array}{l}\text { Lactobacillus fermentum } \\
\text { Lactobacillus }\end{array}$ & 11.67 & 13.66 & $\mathrm{ND}$ & 2.21 \\
$\begin{array}{l}\text { acidophilus } \\
\text { Lactobacillus plantarum }\end{array}$ & 18.00 & 20.33 & 18.00 & 0.75 \\
$\begin{array}{l}\text { Leuconostoc } \\
\text { mesenteroides }\end{array}$ & 14.00 & 17.67 & 20.33 & 1.63 \\
$\begin{array}{l}\text { Pediococcus pentosaceus } \\
\text { Leuconostoc lactis }\end{array}$ & 12.00 & 20.00 & 18.00 & 1.33 \\
\hline
\end{tabular}


Table 5 Effect of different enzymes (catalase and proteinase $K$ ) on the inhibitory property of some lactic acid bacteria against Staphylococcus aureus (ATCC 12600)

\begin{tabular}{|c|c|c|c|c|}
\hline Organisms & $\begin{array}{l}\text { Initial inhibition zone } \\
\text { (mm) }\end{array}$ & $\begin{array}{l}\text { Inhibition zone after } \\
\text { treatment with catalase }\end{array}$ & $\begin{array}{l}\text { Inhibition zone after } \\
\text { treatment with proteinase } k\end{array}$ & SEM \\
\hline Lactobacillus fermentum & $13.00^{\mathrm{a}}$ & $11.67^{\mathrm{a}}$ & $0.67^{\mathrm{b}}$ & 2.00 \\
\hline Lactobacillus acidophilus & $15.00^{\mathrm{a}}$ & $13.67^{\mathrm{a}}$ & $0.667^{\mathrm{b}}$ & 2.30 \\
\hline Lactobacillus plantarum & $12.00^{\mathrm{a}}$ & $11.33^{\mathrm{a}}$ & $1.00^{\mathrm{b}}$ & 1.87 \\
\hline Lactobacillus acidophilus & $13.33^{\mathrm{a}}$ & $12.67^{\mathrm{a}}$ & $0.67^{\mathrm{b}}$ & 2.07 \\
\hline Leuconostoc mesenteroides & $9.67^{\mathrm{a}}$ & 1.00 & $9.00^{\mathrm{a}}$ & 1.45 \\
\hline Identity not confirmed & $7.33^{\mathrm{a}}$ & $0.33^{\mathrm{b}}$ & $7.00^{\mathrm{a}}$ & 1.21 \\
\hline Pediococcus pentosaceus & $9.33^{\mathrm{a}}$ & $0.33^{\mathrm{b}}$ & $8.67^{\mathrm{a}}$ & 1.51 \\
\hline Leuconostoc lactis & $10.33^{\mathrm{a}}$ & $0.33^{\mathrm{b}}$ & $9.67^{\mathrm{a}}$ & 1.67 \\
\hline Control & $15.00^{\mathrm{a}}$ & $13.67^{\mathrm{a}}$ & $0.67^{b}$ & 2.30 \\
\hline
\end{tabular}

Means in the same row with different superscripts are significantly different $(\mathrm{p}<0.05)$

$\mathrm{SEM}=$ standard error of means

Table 6 Effect of different enzymes (catalase and proteinase $K$ ) on the inhibitory property of some lactic acid bacteria against Escherichia coli (ATCC 117755)

\begin{tabular}{lllll}
\hline Organisms & Initial inhibition & $\begin{array}{l}\text { Inhibition } \\
\text { catalase treatment }\end{array}$ & $\begin{array}{l}\text { Inhibition after treatment } \\
\text { with proteinase K }\end{array}$ & SEM \\
\hline Lactobacillus fermentum & $19.33^{\mathrm{a}}$ & $18.67^{\mathrm{a}}$ & $0.33^{\mathrm{b}}$ & 3.13 \\
Lactobacillus acidophilus & $16.33^{\mathrm{a}}$ & $16.00^{\mathrm{a}}$ & $1.00^{\mathrm{b}}$ & 2.55 \\
Lactobacillus plantarum & $15.67^{\mathrm{a}}$ & $15.33^{\mathrm{a}}$ & $0.67^{\mathrm{b}}$ & 2.48 \\
Lactobacillus acidophilus & $17.67^{\mathrm{a}}$ & $17.33^{\mathrm{a}}$ & $0.67^{\mathrm{b}}$ & 2.82 \\
Leuconostoc mesenteroides & $19.67^{\mathrm{a}}$ & $0.67^{\mathrm{b}}$ & $19.00^{\mathrm{a}}$ & 3.14 \\
Identity not confirmed. & $10.33^{\mathrm{a}}$ & $1.00^{\mathrm{b}}$ & $9.33^{\mathrm{a}}$ & 1.53 \\
Pediococcus pentosaceus & $12.33^{\mathrm{a}}$ & $0.00^{\mathrm{b}}$ & $12.00^{\mathrm{a}}$ & 2.04 \\
Leuconostoc lactis & $9.67^{\mathrm{a}}$ & $0.61^{\mathrm{b}}$ & & $9.00^{\mathrm{a}}$ \\
Control (subtilisin) & $15.00^{\mathrm{a}}$ & $13.67^{\mathrm{a}}$ & $0.67^{\mathrm{b}}$ & 1.50 \\
\hline
\end{tabular}

Means in the same row with different superscripts are significantly different from one another $(\mathrm{p}<0.05)$

SEM = standard error of means 